\title{
Secretion and composition of nectar and the structure of perigonal nectaries in Fritillaria meleagris L. (Liliaceae)
}

\author{
M. Stpiczyńska $\cdot$ M. Nepi $\cdot$ M. Zych
}

Received: 7 December 2011/ Accepted: 11 February 2012/Published online: 3 March 2012

(C) The Author(s) 2012. This article is published with open access at Springerlink.com

\begin{abstract}
The structure of perigonal nectaries, nectar production and carbohydrate composition were compared at various stages in the lifespan of the flower of Fritillaria meleagris $\mathrm{L}$. The six nectaries each occupied a groove that is located $2-4 \mathrm{~mm}$ above the tepal base. The average nectary measured $11.0 \mathrm{~mm}$ long and $1.0-1.2 \mathrm{~mm}$ wide. The structure of nectaries situated on both inner and outer tepal whorls was identical, and at anthesis they were equally accessible to potential pollinators. However, secretion from nectaries associated with inner tepals tended to exceed that produced by nectaries located on the outer tepals. On average, regardless of flower stage, one flower secreted $10.87 \pm 12.98 \mathrm{mg}$ of nectar (mean and SD; $N=182$ ). The nectar concentration ranged between 3 and $75 \%$, with average concentration of sugars exceeding $50 \%$. Both nectar production and concentration were dependent on the stage of anthesis, with the highest scores being recorded during full anthesis $(21.75 \pm 16.08 \mathrm{mg} ; 70.5 \%$, mass and concentration, respectively) and the lowest at the end of anthesis $(1.32 \pm 2.69 \mathrm{mg} ; 16.9 \%$, mass and concentration, respectively). A decline in both mass of nectar secreted and nectar concentration during the final stage of anthesis indicates nectar resorption. Nectar was composed of sucrose, glucose and fructose in approx. equal quantities, and its composition did not change significantly during subsequent stages of flowering. The nectaries comprised a single-layered secretory epidermis and several layers of
\end{abstract}

M. Stpiczyńska · M. Zych ( $\square)$

University of Warsaw Botanic Garden,

Aleje Ujazdowskie 4, 00-478 Warsaw, Poland

e-mail: mzych@biol.uw.edu.pl

M. Nepi

Department of Environmental Sciences,

University of Siena, via Mattioli 4, 53100 Siena, Italy subepidermal parenchyma. The nectariferous cells did not accumulate starch during any of the investigated stages. The nectary was supplied with one large and several smaller vascular bundles comprising xylem and phloem. Transport of assimilates and nectar secretion by protoplasts of secretory cells (and probably also nectar resorption) were facilitated by cell wall ingrowths present on the tangential walls of epidermal cells and subepidermal parenchyma. Epidermal cells lacked stomata. Nectar passed across the cell wall and through the cuticle which was clearly perforated with pores.

Keywords Nectar carbohydrates · Nectar secretion . Nectar resorption · Ultrastructure

\section{Introduction}

Floral nectar is the main reward offered by plants to pollinators, and it is produced by specialized secretory structures, the floral nectaries. Owing to the importance of nectaries in pollination, the location of nectar secretion and presentation, combined with nectar quantity and composition, are the main factors in determining potential pollinators among nectar-feeding animals (Simpson and Neff 1983; Pacini et al. 2003; Pacini and Nepi 2007).

Unlike the floral organs, whose relative positions are conserved across the angiosperms, the nectary glands can be found at various floral and extrafloral locations and, according to the studies of Baum et al. (2001), location of the nectary is independent of the $\mathrm{ABC}$ floral homeotic genes. This enables a shift in nectary position over evolutionary time in response to selection imposed by interactions with pollinators. Therefore, nectaries can arise at any position along the receptacle, or equally, can be associated 
with any floral organ (Bernardello 2007, and references therein).

Perigonal type of nectaries are located on perianth parts (tepals, sepals and petals) and they commonly occur in both dicotyledonous and monocotyledonous plants. In the latter, they are found in Liliaceae and several other families, such as Orchidaceae, Triuridaceae, Calochartaceae, Alstroemeriaceae, Luzuriagaceae, Melanthiaceae and Iridaceae. They are present in most members of the subfamily Iridoideae, but in Nivenioideae and Crocoideae, nectaries are of the septal type (Vogel 1998; Rudall et al. 2000; 2003; Smets et al. 2000; Goldblatt and Manning 2008). Perigonal nectaries may be glandular, glabrous or trichomatous and are located at the base of perianth segments in Iridaceae (Rudall et al. 2003) and Liliaceae (Bakhshi Khaniki and Persson 1997; Stolar and Davis 2010).

The position and structure of nectaries and the composition of their nectar provide important taxonomic characters (Percival 1961; Baker and Baker 1983; Endress 1995; Rudall et al. 2000, 2003; Smets et al. 2000; van Wyk 2002; Rønsted et al. 2005; Bernardello 2007). This is also the case for the relatively large genus Fritillaria L., which comprises about 130 species of diverse habit and flower morphology. Furthermore, differences in the position and morphology of nectaries have frequently been used as a basis for subgeneric classifications (Bakhshi Khaniki and Persson 1997; Bakhshi Khaniki 2007).

Although scanning electron microscopy (SEM) studies provide comprehensive information on the morphology of the nectaries in many representatives of Asiatic Fritillaria, there are a paucity of data with regard to the anatomy and ultrastructure of nectaries in this genus. This is also true of the family Liliaceae, which currently contains 16 genera (Fay and Chase 2000). Details of the structure of tepalar nectaries in the Asiatic Lilium hybrid Trésor were recently published (Stolar and Davis 2010).

The aim of the present paper is to investigate the anatomy and ultrastructure of the perigonal nectaries of Fritillaria meleagris L., and in particular, to compare the structure of the nectaries and nectar composition during successive stages of nectary activity. Because the flowers were said to be protogynous (Knuth 1899; Rix 1968), we also checked for differences in nectar availability to pollinators between presumed sexual stages of the flower. Our study plant is self-compatible, but seeds in natural conditions are mostly outcrossed (Zych and Stpiczyńska 2012); therefore, interactions with animal pollinators, including nectar production and presentation, are a crucial step in the plant's reproduction. Flower visitors include bumblebees, honeybees, solitary bees and flies (Knuth 1899; Hedström 1983; Zych and Stpiczyńska 2012). Although the largest pollen loads are transferred by solitary bees, the main pollinators are bumblebees (mostly Bombus terrestris and
B. lapidarius) due to their seasonal and floral constancy, and tolerance of bad weather conditions (Zych and Stpiczyńska 2012). As shown by these authors, the flowers of this early-spring flowering species have very a low visitation rate despite being large and showy; we were, therefore, also interested in whether the plant reabsorbs secreted nectar that is not utilized by insect visitors.

\section{Materials and methods}

Study site

The plants of $F$. meleagris L. (Liliaceae) used in this study came from the natural locality of the species, namely the Szachownica w Krównikach nature reserve (the largest population of $F$. meleagris in Poland). The reserve occupies an area of 16.7 ha in the village of Krówniki, near Przemyśl (SE Poland, central point N49 $46^{\prime} 19^{\prime \prime}$ E22 $2^{\circ} 50^{\prime} 59^{\prime \prime}$ ). Since 1946, the species has been legally protected in Poland and is currently included in the "critically endangered" category of the Polish red list. It is also red-listed or bears the status of "rare plant" in other European countries within its natural range, and is regarded as "vulnerable" for the whole of Central Europe (Zych and Stpiczyńska 2012, and references therein).

Field observations: phenology, sexual stages and nectar production

In 2009-2011, in order to assess flower longevity and period of nectar production, we randomly marked 20 plants bearing unopened flower buds. Twice daily (in the morning and again in the afternoon), we checked the plants and noted the progress of flowering stages (stage 0 -closed bud, about 5 days before opening; stage 1 -bud opening with anthers closed; stage 2-beginning of anthesis and pollen presentation, i.e. at least one anther dehisced; stage 3-full anthesis, when all anthers dehisced; stage 4-end of anthesis; stage 5-flower wilting) and the presence of nectar.

\section{Nectar sampling}

The initial and final stages of nectar production were assessed on the basis of observations made on the progress of flowering. Nectar was sampled from the flowers at the first day of anthesis (stage 2), from the 3- to 3.5-day-old flowers (stage 3), and at the final stage of anthesis (approx. 5-6th flowering day, stage 4). For this purpose, samples of 20 flowers designated for nectar sampling at appropriate stages were chosen randomly while the buds were still closed (about 5 days before opening) and bagged with a nylon net (mesh $0.5 \mathrm{~mm}$ ) to prevent visits by insects. When 
the flower reached the required stage of development, the nectar from each of three nectaries associated with the outer whorl (as one sample per flower) was carefully sampled with microcapillary pipettes of known mass and then repeated for three nectaries associated with the inner whorl (also as one sample per flower). The microcapillaries containing nectar were reweighed using an analytical balance AS 60/220/C/2 (RADWAG, Radom, Poland) in order to determine the mass of secreted nectar. Nectar was subsequently expelled from the microcapillary onto an RL-4 or RL-3 refractometer prism (PZO, Warszawa, Poland) in order to measure nectar sugar concentration (as percentage nectar concentration by weight).

In 2009, in order to check for changes in the composition of nectar sugars throughout the lifetime of the flower, nectar from five flowers (but this time, without distinction between nectaries associated with outer and inner whorl) for each stage of development (2-4) was collected with wicks of Whatman paper no. 1 of known mass. The nectar-laden wicks were immediately weighed on an analytical balance, then were air-dried and stored at $-20^{\circ} \mathrm{C}$ prior to analysis. The samples were thawed to ambient temperature and nectar was then recovered from the filter paper by static elution with $100 \mu \mathrm{l}$ distilled water for 3-4 min, followed by centrifugation for $5 \mathrm{~min}$ at $11,000 \mathrm{~g}$ (rcf). The supernatant was analysed by isocratic HPLC using an LC1 Waters system. A 20- $\mu \mathrm{l}$ sample and standard solution were injected. Water (MilliQ, pH 7), with a flow rate of $0.5 \mathrm{ml} / \mathrm{min}$, was used as the mobile phase. Sugars were separated in a Waters Sugar-Pack I column $(6.5-300 \mathrm{~mm})$ maintained at $90^{\circ} \mathrm{C}$ and identified by a refractive index detector (Waters 2410). The contents of fructose, glucose and sucrose were determined and expressed as a percentage of total sugars.

\section{Microscopic observations}

The structure of nectaries was studied for the flowers at the stage of bud opening (stage 1) and from stages 2 to 4 . The distribution of nectaries derived from fresh flowers was recorded, and an examination of their surface undertaken using a Nikon SMZ 1000 stereomicroscope (Nikon Corp., Tokyo, Japan). The nectaries were then prepared for histochemical investigations by means of light microscopy (LM), transmission electron microscopy (TEM) and SEM. For bright field LM, hand-cut sections from fresh nectaries were stained for lipids and starch using an alcoholic solution of Sudan IV and IKI, respectively (Jensen 1962). Semi-thin sections of nectaries were prepared by fixing nectary tissue in $2.5 \%$ glutaraldehyde $/ 4 \%$ formaldehyde in phosphate buffer $(\mathrm{pH} 7.4 ; 0.1 \mathrm{M})$ for $4 \mathrm{~h}$ at $4^{\circ} \mathrm{C}$, followed by three washes in phosphate buffer. Samples were subsequently dehydrated in a graded ethanol series and infiltrated with LR White resin. Following polymerization at $60^{\circ} \mathrm{C}$, the sections were cut with a glass knife at a thickness of $0.9-1.0 \mu \mathrm{m}$. For general histology, semi-thin sections were stained with $0.25 \%$ toluidine blue O (TBO) in $0.25 \%$ $(\mathrm{w} / \mathrm{v})$ aqueous sodium tetraborate solution (O'Brien and McCully 1981) or with Multiple Stain Solution (MSS) (Polysciences, Inc., Eppelheim, Germany) (that appears to differentiate cell walls more effectively), used according to the protocol provided by the manufacturer. LM observations were conducted using a Nikon Eclipse 400 (Nikon Corp., Tokyo, Japan) microscope and measurements were taken with NIS-Elements $\mathrm{Br} 2$ imaging software (Nikon Corp., Tokyo, Japan).

The sections were also examined by means of fluorescence microscopy (FM). In order to test for the presence of callose and cutinized cell walls, semi-thin sections were stained with aniline blue and auramine $\mathrm{O}$, respectively (Johansen 1940; Heslop-Harrison 1977; Gahan 1984). A Nikon 90i fluorescence microscope with UV2A filter (EXP. 378/11; DM 416; BA 416 LP) was used for sections stained with aniline blue, whereas a FITC filter (EXP. 465-495, DM 505; BA 515-555) was used for sections stained with auramine $\mathrm{O}$. Autofluorescence of hand-sectioned material, when illuminated with UV light, was used to detect the distribution of chloroplasts and lignified nectary cells. Photomicrography was undertaken using either a Nikon 90i fluorescence microscope with digital camera (Nikon Fi1) and NIS-Elements Br 2 software, or a Zeiss AxioImager Z1 fluorescence microscope equipped with an AxioCam MR digital camera.

Material for TEM was fixed as above, but then postfixed in $1 \%$ osmium tetroxide solution at $0^{\circ} \mathrm{C}$ for $1.5 \mathrm{~h}$, washed in distilled water and dehydrated using a graded ethanol series and embedded in LR White resin. Ultra-thin sections were cut with a glass knife at $60 \mathrm{~nm}$ using a Reichert Ultracut-S ultramicrotome (Reichert Jung, Wetzlar, Germany), stained with uranyl acetate and lead citrate (Reynolds 1963) and examined using Zeiss Leo EM 912 (Zeiss SMT GmbH, Göttingen, Germany) transmission electron microscope, at an accelerating voltage of $90 \mathrm{kV}$.

For SEM observations, nectaries fixed as above were dehydrated in acetone, subjected to critical-point drying using liquid $\mathrm{CO}_{2}$, sputter-coated with gold and examined using a TESCAN/VEGA LMU SEM (TESCAN, Brno, Czech Republic) at an accelerating voltage of $30 \mathrm{kV}$.

\section{Results}

Nectar secretion, concentration and composition

The floral nectar of F. meleagris was secreted by tepalar nectaries positioned adaxially on each of six perianth segments (Fig. 1a, b). The nectaries were depressed in a 

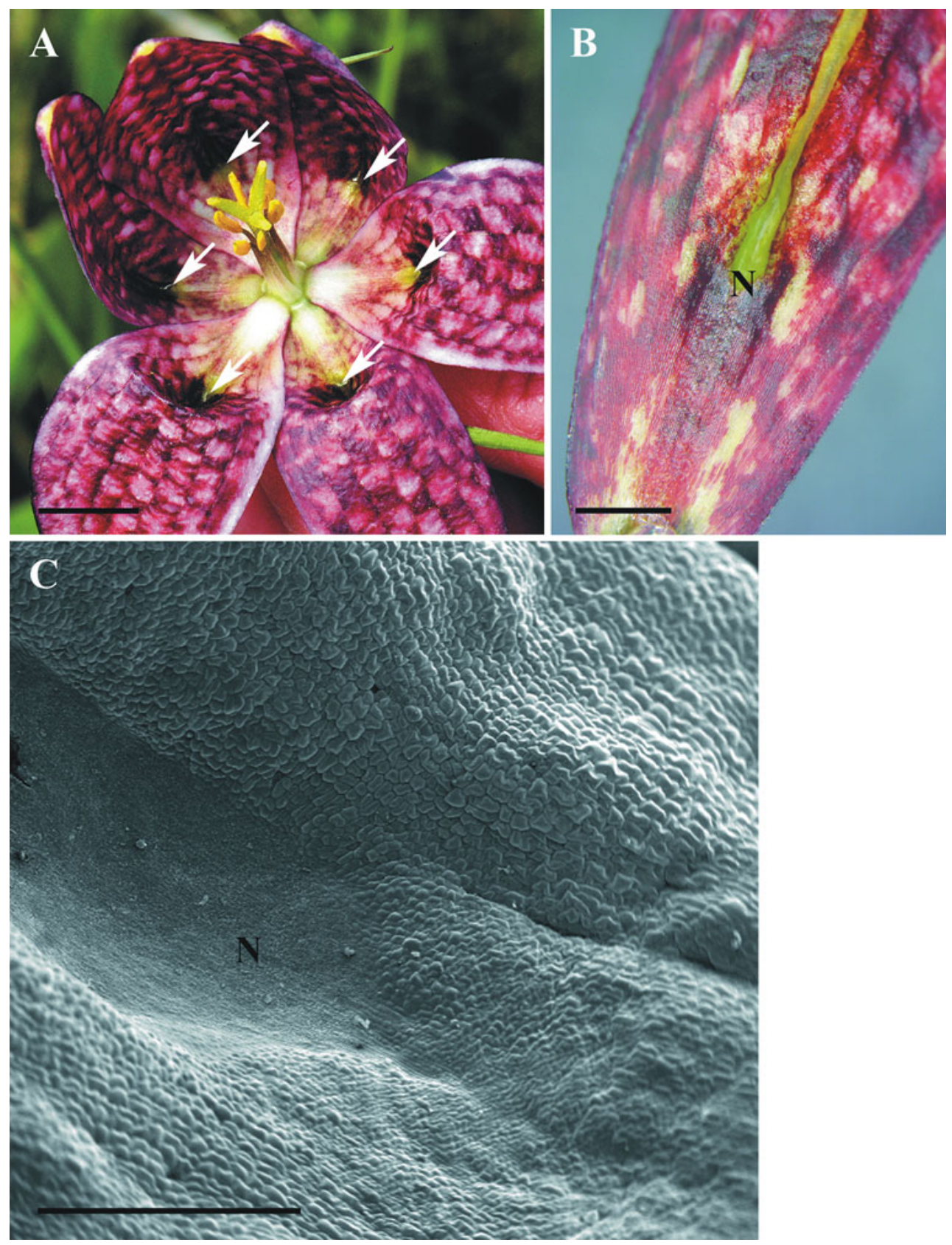

Fig. 1 a-c Position of tepalar nectaries in Fritillaria meleagris. a Nectar presented by nectaries located at the bases of six tepals (arrows) that are arranged in two whorls of three is equally accessible to pollinators. Scale bar $10 \mathrm{~mm}$. b The light green nectary $(N)$ is set

groove located $2-4 \mathrm{~mm}$ above the base of the tepal (Fig. 1b, c). The proximal part of the nectary was wider (mean $5.4 \mathrm{~mm}$ ) than the remaining part (range $1.0-1.2 \mathrm{~mm}$ wide). The length of the whole nectary varied from 9.12 to $14.43 \mathrm{~mm}(11.0 \pm 1.49 \mathrm{~mm}$; mean and SD). All the nectaries, regardless of whether they were located on the inner or outer tepals, were of similar size and, at anthesis, were equally accessible to potential pollinators (Fig. 1a). The light green nectaries contrasted markedly with the white against a contrasting background provided by the tessellated tepal. Scale bar $5 \mathrm{~mm}$. c Depression at the distal end of nectary, SEM. Scale bar $1 \mathrm{~mm}$

and dark-purple patterned tepals (Fig. 1a, b), However, some nectariferous cells appeared coloured, as they contained anthocyanins.

On average, a single tepalar whorl secreted $5.43 \pm$ $6.64 \mathrm{mg}$ of nectar, whereas one flower secreted $10.87 \pm$ $12.98 \mathrm{mg}$ of nectar. The nectar concentration ranged between 3 and $75 \%$, with average sugar concentration exceeding 50\% (means and SDs calculated across years and floral stages). However, both nectar production and 
Fig. 2 a-b Nectar characteristics in Fritillaria meleagris during a 3-year study of a natural population in SE Poland: a average nectar production per flower $(\mathrm{mg})$; and $\mathbf{b}$ average nectar sugar concentration $(\%, \mathrm{w} / \mathrm{w})$. Error bars indicate 0.95 confidence interval
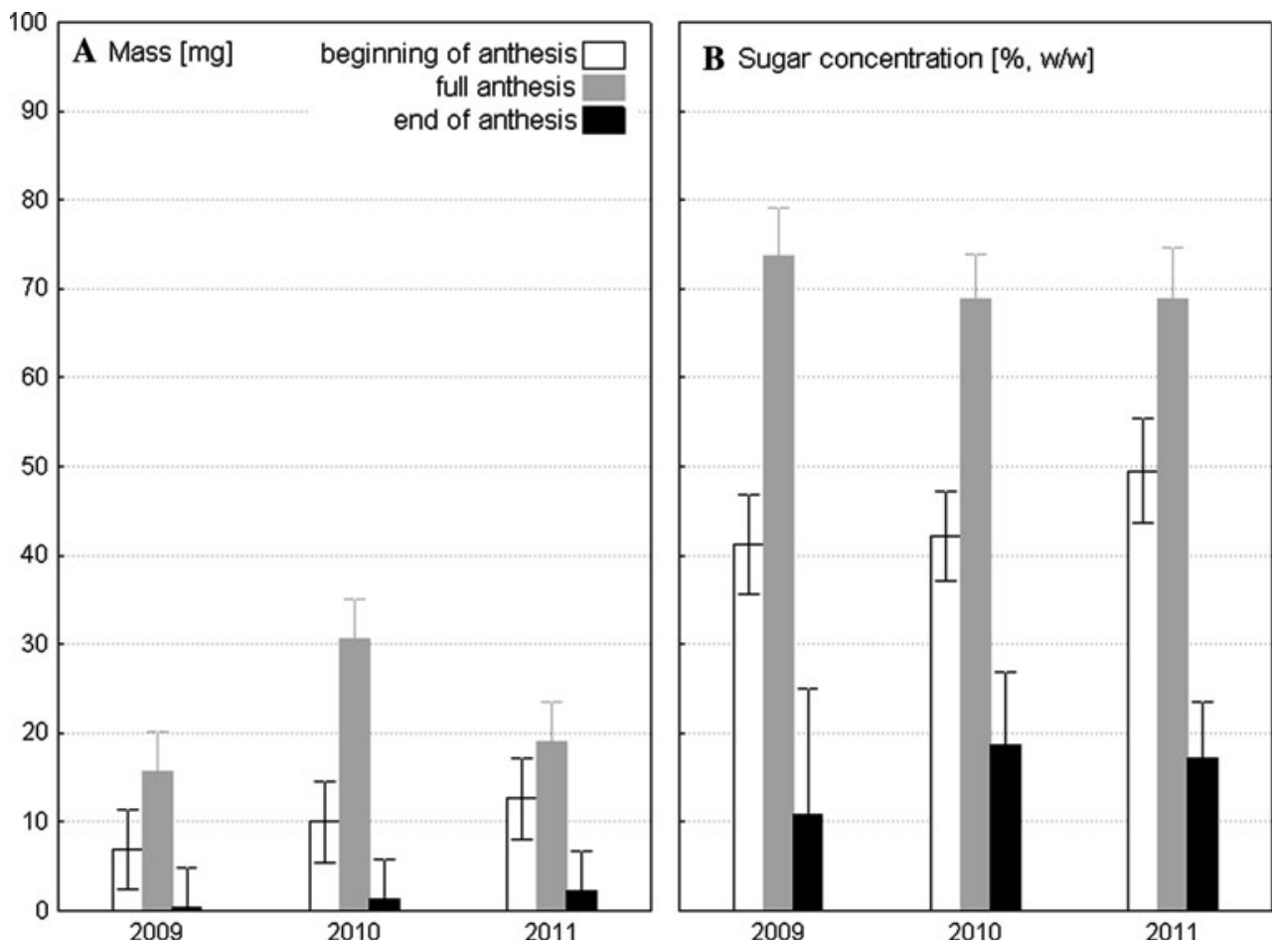

concentration were dependent on the floral stage sampled (two-way ANOVAs with study year and flower stage as factors: $F_{2,173}=74.496$ for nectar mass and $F_{2,92}=$ 113.716 for nectar concentration; $p \ll 0.001$ for both variables), with the highest scores, on average, obtained for flowers displaying full anthesis $(21.75 \pm 16.08 \mathrm{mg} ; 70.5 \%$ mass and concentration, respectively) and the lowest towards the end of anthesis $(1.32 \pm 2.69 \mathrm{mg} ; 16.9 \%$ mass and concentration, respectively). Intermediate results were obtained for flowers at the beginning of anthesis $(9.85 \pm 5.81 \mathrm{mg}, 44 \%$ mass and concentration, respectively; Fig. 2). Nectar production also varied from year to year (two-way ANOVA on nectar mass with study year and flower stage as factors, $F_{2,173}=7.109, p<0.002$ ); the greatest and lowest values being obtained for 2010 and 2009, respectively (Fig. 2). When the perianth whorls were considered separately, the inner three tepals (inner whorl) produced approx. 20\% more nectar than the outer whorl (multivariate ANOVA on nectar mass with study year, floral stage and tepal position as factors: $F_{1,346}=6.292$, $p<0.02$ for outer vs. inner whorl).

The nectar contained sucrose, glucose and fructose in approx. equal quantities, with fructose slightly exceeding glucose and sucrose in the nectar profile of all stages investigated (33:28:39, sucrose/glucose/fructose ratio expressed as a relative percentage of total sugars; means calculated across flowering stages). No other sugars were detected in the nectar. Nectar composition did not change significantly during subsequent stages of flowering (Fig. 3).
Small droplets of nectar appeared on the surface of the nectary at a stage when the buds were just opening (stage 1, Fig. 4a), the anthers had not dehisced and the stigma was not receptive. Nectar was still present on the nectary surface until stage 4 , but then disappeared. This coincided with tepals losing their turgor and the flower reassuming a bud-like form.

The structure of nectaries

The nectary consisted of a single-layered epidermis lacking stomata and 3-4 layers of subepidermal nectariferous parenchyma (Fig. 4b-h). The epidermis was composed of small cells, some $33.85 \times 25.16 \mu \mathrm{m}$ in diameter. The cytoplasm of each epidermal cell stained intensely and contained a large, centrally located nucleus, several small vacuoles and proplastids (Fig. 4c-e, g).

Subepidermal nectariferous parenchyma cells had a mean diameter of $34.45 \mu \mathrm{m}$. They contained larger vacuoles than epidermal cells. Vacuoles had translucent contents and were traversed by cytoplasmic strands (Fig. 4c-e, g). Perinuclear and parietal cytoplasm contained numerous plastids (Fig. 4c). Plastids were also located more deeply within the nectariferous parenchyma, but these cells showed only pale red autofluorescence (Fig. 4h). Treatment with IKI did not reveal the presence of starch in the plastids of nectariferous cells.

Nectariferous tissue (measured above midrib, at the proximal end of the nectary) was $255.71-380.5 \mu \mathrm{m}$ deep, 


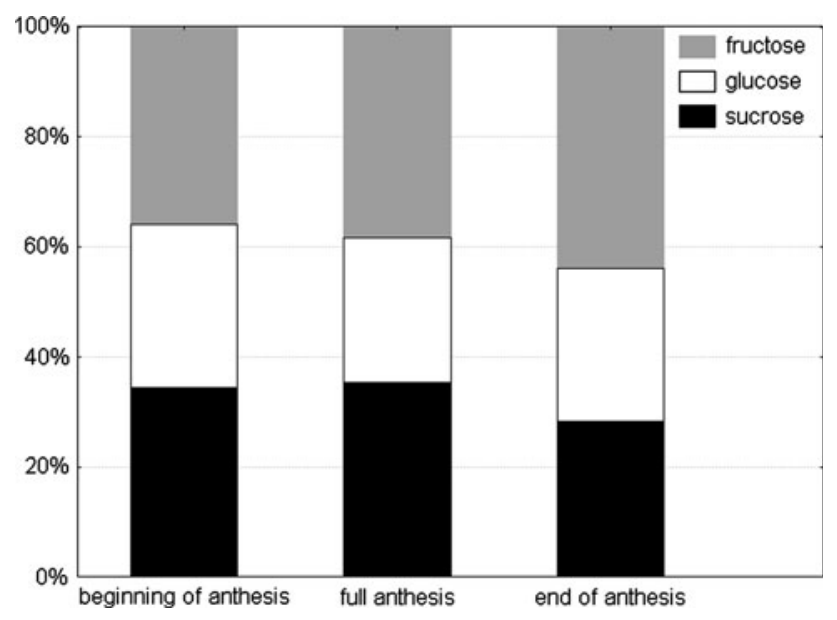

Fig. 3 Nectar sugar composition in Fritillaria meleagris at successive stages of flower development. Sucrose, glucose and fructose contents are expressed as a relative percentage of total sugars

and similar values were also recorded for subsequent stages of nectary activity. Beneath the nectary tissue lay several layers of larger ground parenchyma cells having prominent intercellular spaces. The nectary was supplied by a single, main vascular bundle and several small bundles that ended in the subepidermal secretory layer (Fig. $4 b, d, h$ ). These bundles contained xylem and phloem elements.

Treatment with TBO revealed that the walls of secretory cells contained cellulose and pectins. Staining with Sudan $\mathrm{IV}$ and auramine $\mathrm{O}$ did not indicated the presence of suberized parts in the cell walls (Fig. 4d-e, g). Furthermore, aniline blue did not reveal the presence of callose in the cell walls at the beginning of anthesis (Fig. 4f). The thickness of the primary wall varied considerably (Fig. 4e). For example, on average, the outer tangential epidermal wall measured $2.25 \mu \mathrm{m}$ thick, whereas the inner tangential wall measured $3.15 \mu \mathrm{m}$. Both were distinctly thicker than the radial walls $(0.45 \mu \mathrm{m}$, on average). Similar differences in cell wall thickness were also recorded for subsequent stages of nectary activity. Cell walls of nectariferous parenchyma cells were more uniformly thick and, on average, measured $0.54 \mu \mathrm{m}$.

Outer walls of epidermal cells were covered with a thick cuticle. The structure and thickness of the cuticle were uneven and ranged from 0.5 to $3.12 \mu \mathrm{m}$. The cuticle, although it did not fluoresce with auramine O (Fig. 4g), nevertheless stained red with Sudan IV (Fig. 4e) and fluoresced an intense red with UV light (Fig. 4h). Frequently, blisters of cuticle were noted (Fig. 4f). TEM observations revealed granular, electron-dense cytoplasm enclosing numerous rough endoplasmic reticulum profiles (rER) that often accumulated in the parietal cytoplasm, secretory vesicles, mitochondria and small vacuoles with flocculent or globular contents. Also, dictyosomes were frequently observed (Fig. 5a, b). Plasmodesmata were rarely encountered, but when present, were mainly found in the radial walls of epidermal cells.

The availability of the secreted nectar increased concomitantly with anthesis (stage 2), and the whole nectary groove became filled with nectar (Fig. 6a). SEM revealed that the secretory surface was clearly different from that of the non-secretory region, because the cuticle had distinct swellings that usually coincided with the position of the middle lamella between adjoining epidermal cells (Fig. 6b).

The size of the epidermal cells and nectariferous parenchyma tended to increase slightly when compared with stage 1 and measured $38.12 \times 31.46 \mu \mathrm{m}$ and $42.05 \times 43.28 \mu \mathrm{m}$, respectively. In particular, the vacuoles of both types of cell were larger than those found in stage 1 and occupied a greater proportion of some subepidermal parenchyma cells (Fig. 6c). LM observations of this developmental stage also revealed the presence of epidermal and subepidermal cells with intensely stained cytoplasm and large nuclei (Fig. 6d). Starch was absent from nectariferous tissue, but was present in minute quantities in phloem and xylem parenchyma cells. The middle lamella cementing the inner tangential wall of the epidermis to that of the adjacent parenchyma cell was relatively thick (Fig. 6c), and intercellular spaces were occasionally observed. Staining of sections with aniline blue for FM revealed the presence of callose within the cell walls of nectariferous tissue. Furthermore, in stage 2, nectariferous parenchyma cells only fluoresced pale red when subjected to UV light.

The thick cuticle of epidermal cells stained red with Sudan IV. As in stage 1, the cuticle fluoresced pale red with UV light, but did not stain with auramine $\mathrm{O}$, and microchannels were present in the cuticle (Fig. 6e). At stage 2, inconspicuous, labyrinthine cell wall ingrowths appeared in the outer tangential walls of epidermal cells and in the subepidermal parenchyma (Fig. 6d, e). Under LM, these stained intensely with MSS. This reagent stained the cytoplasm only slightly, thus producing much better contrast than other stains. Ingrowths penetrated the cell lumen to a depth of ca. $2 \mu \mathrm{m}$. TEM observations indicated a close association between rER and wall ingrowths (Fig. 6e). At this stage, the cytoplasm had a similar granular appearance to that of cells at stage 1 . However, small vacuoles had accumulated, mainly at the centre of the cell (Fig. 6f). In the parietal cytoplasm, especially near the plasmalemma, osmiophilic droplets were present (Fig. 6e). Plastids present in secretory epidermal cells contained dark stroma (Fig. 6f) with several small plastoglobuli, but few lamellae.

At full anthesis (stage 3), the nectaries were completely covered with secretion and nectar extended beyond the nectary groove (Fig. 7a). SEM revealed numerous cuticular blisters. These were larger than in the previous stage and were distributed along the outer epidermal cell walls 

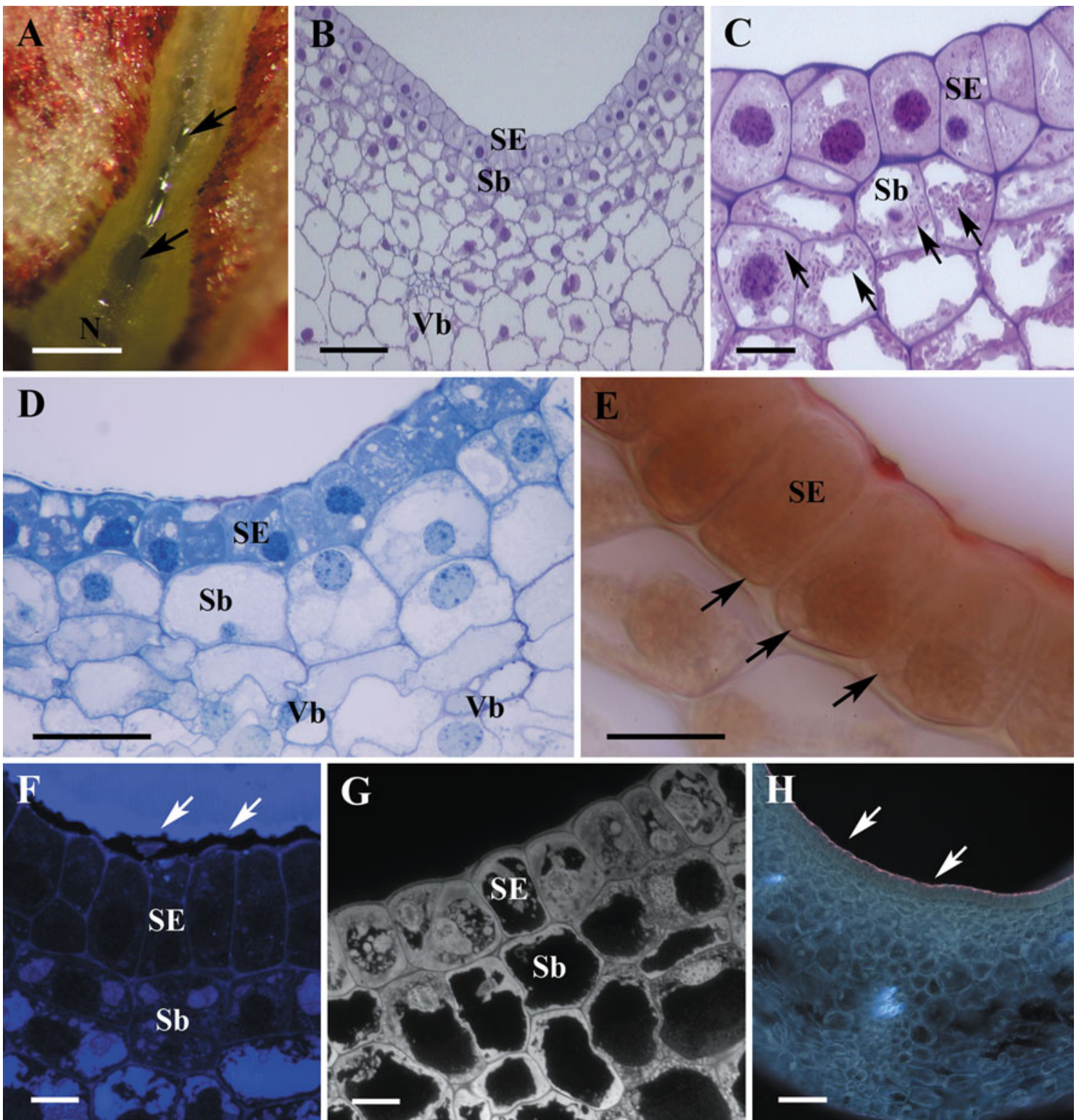

Fig. 4 a-h Nectary at the opening bud stage (stage 1) LM. a Small volume of nectar (arrows) in the nectary groove. Scale bar $10 \mathrm{~mm}$. b Transverse section of nectary showing secretory epidermis, subsecretory parenchyma and ground parenchyma with vascular bundle, staining with MSS. Scale bar $100 \mu \mathrm{m}$. c Intensely stained cytoplasm of secretory epidermal cells and subepidermal parenchyma with plastids (arrows), staining with MSS. Scale bar $20 \mu \mathrm{m}$. d Vascular strands ending in nectariferous parenchyma, staining with TBO. Scale bar $50 \mu \mathrm{m}$. e Cuticle on the surface of secretory epidermis stained red with Sudan IV. Note thick inner, tangential cell

(Fig. 7b). Often, perforations were visible on these cuticular blisters, as well as nectar residues.

As in the earlier stages, nectariferous cells contained dense, intensely stained protoplasts with large nuclei (Fig. 7c, d), and starchless plastids could be seen in the parenchyma (Fig. 7e). At stage 3, cell wall ingrowths of epidermal and subepidermal cells were more prominent wall between epidermal cells and subepidermal parenchyma (arrows). Scale bar $20 \mu \mathrm{m}$. f Staining with aniline blue does not reveal the presence of callose in the walls of nectary cells. Arrows indicate nectar accumulated beneath and on the surface of the cuticle. Scale bar $20 \mu \mathrm{m}$. g Nectariferous cells do not stain for lipids with auramine O. Scale bar $20 \mu \mathrm{m}$. h Red autofluorescence of cuticle (arrows) when exposed to UV light. By contrast, vascular bundles fluoresce blue. Section unstained, from fresh material. Scale bar $100 \mu \mathrm{m}$. $N$ nectary, $S b$ subsecretory parenchyma, $S E$ secretory epidermis, $V b$ vascular bundle

and longer (Fig. 7d, f, g), but, in contrast to the previous stage, TEM observations also revealed that these outgrowths became coated with a thin layer of callose (Fig. 8a-c). This substance was detectable using FM following staining with aniline blue (Fig. 7f). Ingrowths occurred not only on tangential walls, but also on parts of the radial walls of epidermal cells (Fig. 8c). The layer of 

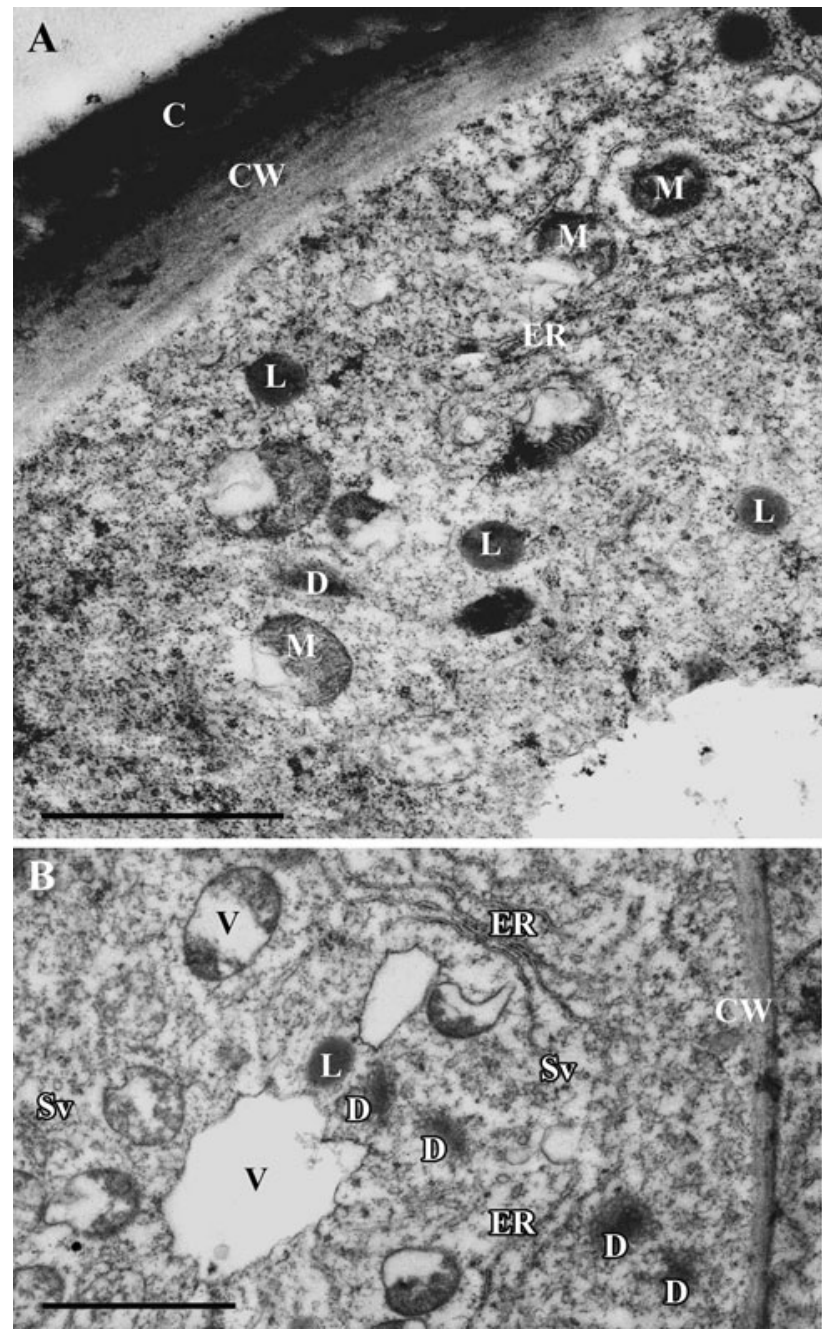

Fig. 5 a-b Nectary at the opening bud stage (stage 1) TEM. a Cell wall of secretory epidermis covered with thick cuticle. In the parietal, granular cytoplasm occur mitochondria, profiles of ER and lipid droplets. Scale bar $2 \mu \mathrm{m}$. b Small vacuoles located in central part of the cell. Scale bar $2 \mu \mathrm{m}$. $C$ cuticle, $C W$ cell wall, $E R$ endoplasmic reticulum, $D$ dictyosome, $L$ lipid droplet, $M$ mitochondrion, $S v$ secretory vesicle, $V$ vacuole

callose coating the radial walls and tangential walls of subepidermal parenchyma was not visible using TEM (Fig. 8d-f). The outer tangential walls of epidermal cells were covered with blistered cuticle containing microchannels (Fig. 8a). The electron-dense cytoplasm mainly contained secretory vesicles and small vacuoles with flocculent contents, but in contrast to stage 2 , they were found close to the cell wall ingrowths and in the central cytoplasm (Fig. 8c-e).

At the final stage of anthesis (stage 4) only nectar residues were present on the surface of the nectary. Some cells of the nectariferous epidermis still contained dense cytoplasm, but others contained less dense or watery cytoplasm, or had completely collapsed (Fig. 9a-d). The epidermal cuticle did not stain with auramine $\mathrm{O}$.
Fig. 6 a-f Nectary at the beginning of anthesis (stage 2) stereoscope microscope, SEM, LM and TEM. a Nectary groove coated with nectar (arrows). Scale bar $1.5 \mathrm{~mm}$. b Border between nectariferous and non-secretory surface. Blistered cuticle (arrow) with underlying nectary epidermal cells. Scale bar $60 \mu \mathrm{m}$. c Secretory epidermal cells with cytoplasm that stains intensely with TBO and subepidermal cells with large vacuoles. Note thick tangential cell walls (arrows). Scale bar $20 \mu \mathrm{m}$. d Cell wall ingrowths (arrows) visible on tangential cell walls, staining with MSS. Scale bar $20 \mu \mathrm{m}$. e Outer cell wall of epidermal cell covered with thick, reticulate cuticle. The wall develops small protuberances (asterisks) that project into the protoplast. Mitochondria, ER and secretory vesicles are visible in the cytoplasm. f Mitochondria, small vacuoles and starchless plastids are centrally located in the cell. e, $\mathbf{f}$ scale bars $2 \mu \mathrm{m}$. $C$ cuticle, $C W$ cell wall, $E R$ endoplasmic reticulum, $L$ lipid droplet, $M$ mitochondrion, $N$ nectary, $P$ plastid, $S b$ subsecretory parenchyma, $S E$ secretory epidermis, $S v$ secretory vesicle, $V$ vacuole

Furthermore, the red autofluorescence produced on exposure to UV light was less intense, and the cuticle fluoresced pale blue. Cell wall ingrowths did not disappear with a decline in secretory activity (Fig. 9c, e, f) and callose remained a component of the cell wall. Numerous secretory vesicles of various size, together with small vacuoles, occurred in cytoplasm. These had darker and more compact contents than cells in previous stages of nectary activity (Fig. 9g). In subepidermal parenchyma cells, the cytoplasm tended to be electron-transparent and most organelles lost their structural integrity.

\section{Discussion}

Nectar secretion and resorption

Our studies on the pollination biology of $F$. meleagris showed that the flowers are homogamous and that stigma receptivity and anthers dehiscence occur simultaneously (Zych and Stpiczyńska 2012). Therefore, protogyny in this species, as previously reported by Knuth (1899), was not confirmed. Moreover, the period of maximum nectar secretion overlapped with maximum pollen presentation and stigmatic receptivity. Accumulation of the rewards (nectar and pollen) at a given time may enhance the attractiveness of the flower to pollinators and allow maximum benefit from just a single visit, especially because the frequency of pollinator visits to the flowers of the European Fritillary is so low. Indeed, during 3 years of observations, we noted only about 0.2 visits/flower/h (Zych and Stpiczyńska 2012). However, the presence of nectaries alone most probably does not affect attractiveness of the flowers as they are green and invisible to pollinators from outside of the flower, contrary to the nectaries of ornithophilous Fritillaria species (Cronk and Ojeda 2008).

The flowers of $F$. meleagris produce a considerable amount of pollen and nectar and these are an important 

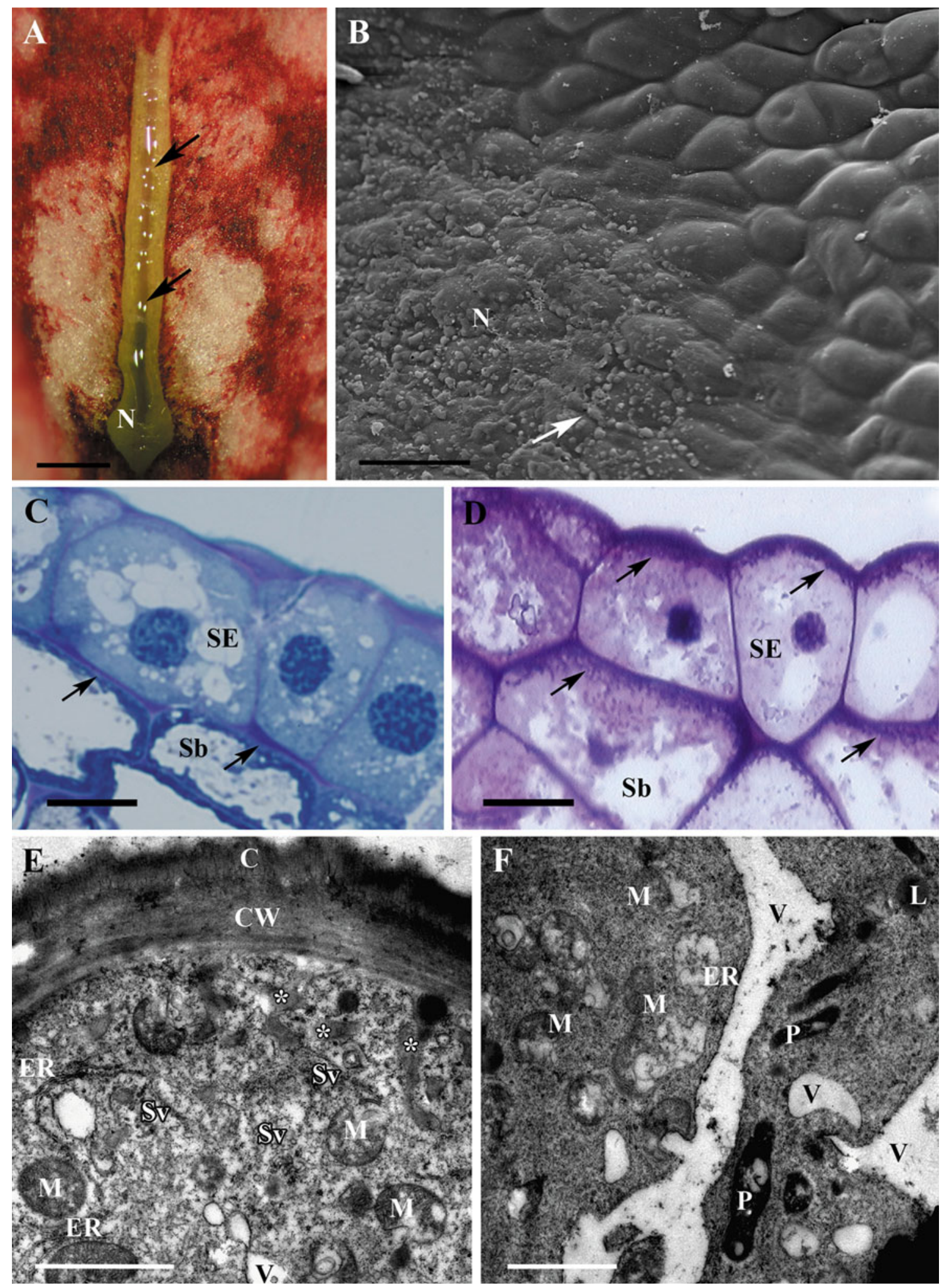

food source for hymenopterans visiting the plants during early spring. The nectar was relatively concentrated and was presented on a relatively exposed surface of each nectary within the flower. In F. meleagris, there are no furrows or lobes present as in some other Fritillaria (Bakhshi Khaniki and Persson 1997) and Lilium species 

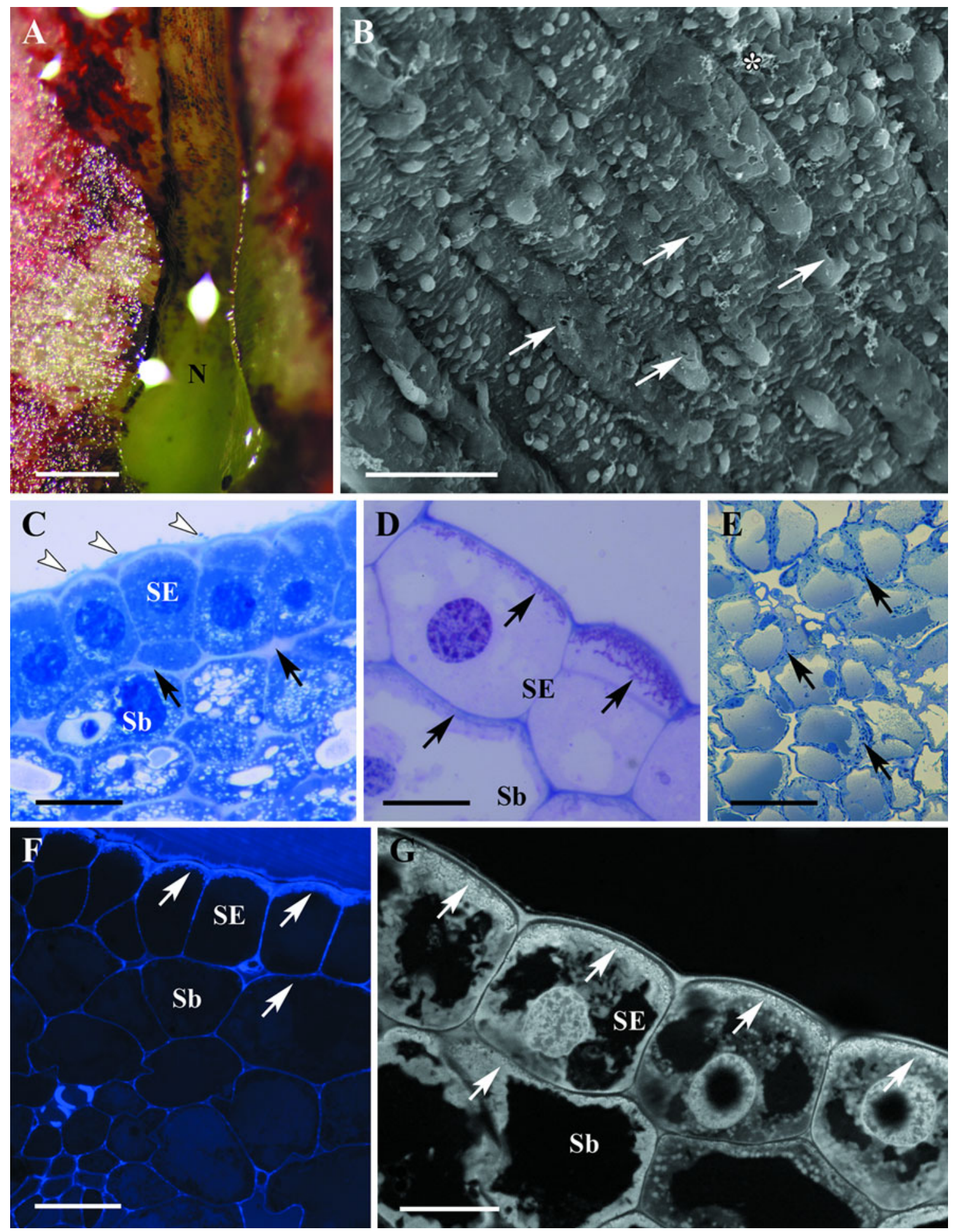

Fig. 7 a-g Nectary at full anthesis (stage 3) stereoscope microscope, SEM and LM. a Nectary groove completely coated with nectar that extends beyond the secretory surface. Scale bar $1 \mathrm{~mm}$. b Large blisters of cuticle with pores (arrow) and nectar residues (asterisk). Scale bar $20 \mu \mathrm{m}$. c Secretory epidermis and nectariferous parenchyma with intensely stained cytoplasm, staining with TBO. Note thick tangential cell wall between epidermal and subepidermal cell (arrows) and secretion on the surface of epidermis (arrowheads).
Scale bar $40 \mu \mathrm{m}$. d Cell wall ingrowths of tangential walls (arrows). Scale bar $20 \mu \mathrm{m}$. e Starchless plastids present in deeper layers of nectariferous parenchyma (arrows). Scale bar $50 \mu \mathrm{m}$. f Callose on secretory epidermal cell walls with ingrowths stains blue with aniline blue (arrows). Scale bar $40 \mu \mathrm{m}$. g Cell wall ingrowths of tangential cell walls of nectariferous cells (arrows). Cuticle is not stained with auramine O. Scale bar $20 \mu \mathrm{m}$. $N$ nectary, $S b$ subsecretory parenchyma, $S E$ secretory epidermis 

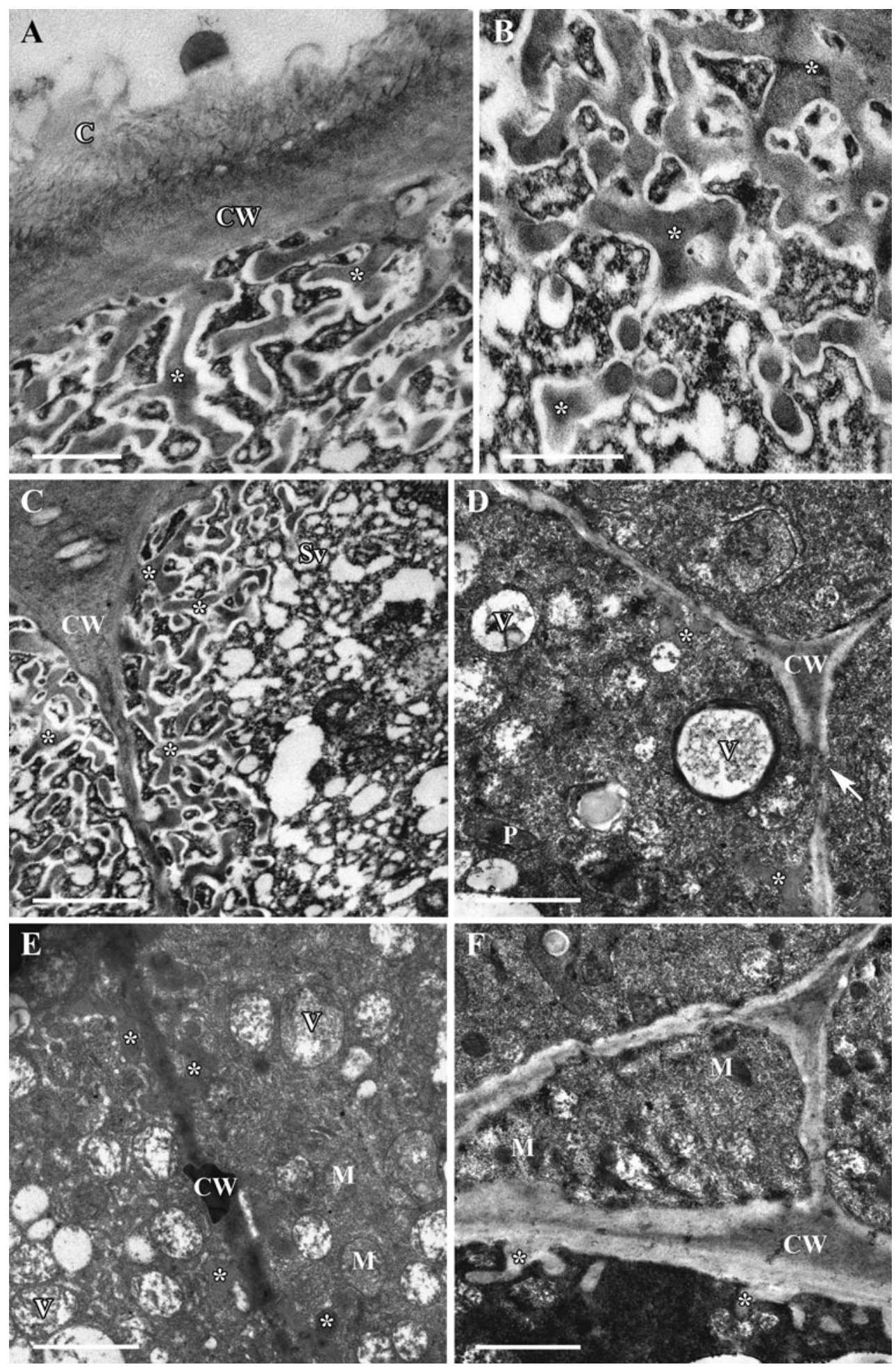

Fig. 8 a-f Nectary at full anthesis (stage 3) TEM. a Cell wall with blistered, reticulate cuticle. Wall protuberances (asterisks) coated with thin layer of callose. b Detail of labyrinthine protuberances (asterisks) with light outer layer of callose. a, b scale bar $1.0 \mu \mathrm{m}$. c Cell wall ingrowths (asterisks) are occasionally present on radial walls of epidermal cells. Numerous secretory vesicles occur in parietal cytoplasm. d Small vacuoles with flocculent content in central part of epidermal cell. Short ingrowths (asterisks) and plasmodesmata (arrow) in radial wall. e Small vacuoles with flocculent content and mitochondria in parietal, granular cytoplasm. Cell wall ingrowths marked by asterisks. f Thick cell wall with short ingrowths (asterisks), between epidermal and subepidermal cells (slightly paradermal section). c-f scale bar $2.0 \mu \mathrm{m}$. $C$ cuticle, $C W$ cell wall, $M$ mitochondrion, $P$ plastid, $S v$ secretory vesicle, $V$ vacuole 

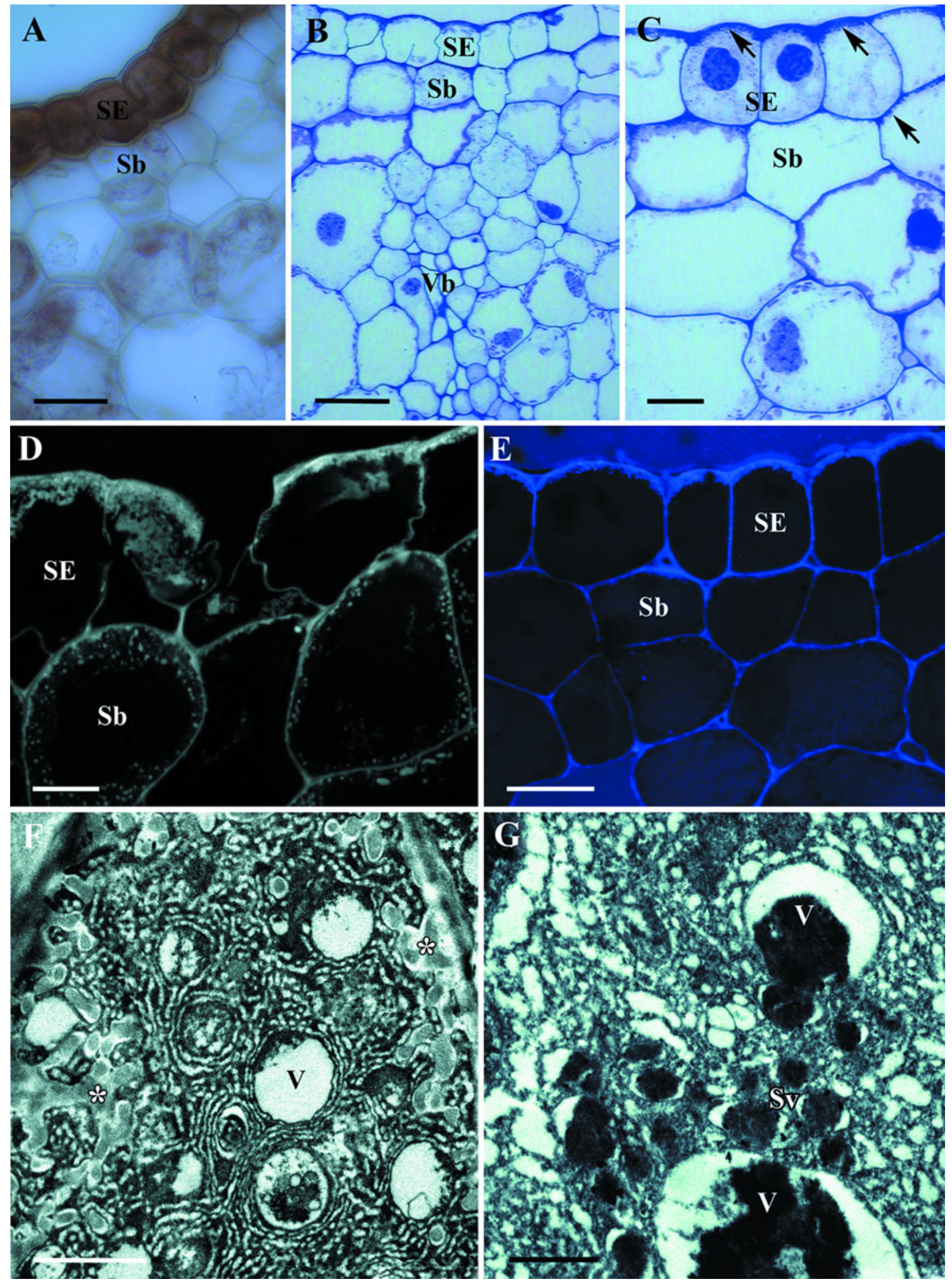

Fig. 9 a-g Nectary at final stage of anthesis (stage 4) LM, TEM. a Secretory epidermis with dense cytoplasm. Treatment with IKI reveals the absence of starch. b Less dense cytoplasm of both secretory epidermis and subepidermal parenchyma above midrib, staining with MSS). a, b Scale bar $50 \mu \mathrm{m}$. c Cell wall ingrowths of tangential walls (arrows), staining with MSS. Scale bar $20 \mu \mathrm{m}$. d Collapsed secretory epidermal cell. Scale bar $10 \mu \mathrm{m}$. e Callose visible on cell walls following staining with aniline blue. Scale bar $40 \mu \mathrm{m}$. f Cell wall ingrowths (asterisks), and small vacuoles surrounded by ER in parietal cytoplasm of epidermal cell. Scale bar $2.0 \mu \mathrm{m}$. g Detail of small vacuoles and vesicles with osmiophilic content. Scale bar $1.0 \mu \mathrm{m}$. Sb subsecretory parenchyma, $S E$ secretory epidermis, $S v$ secretory vesicle, $V$ vacuole, $V b$ vascular bundle 
(Stolar and Davis 2010) that could restrict the feeding of insects with relatively long proboscises on nectar. However, the nodding of flowers of $F$. meleagris limits access to the reward to a relatively small group visitors, predominantly large Hymenoptera (Zych and Stpiczyńska 2012). On the other hand, the pendant flowers of $F$. imperialis L. are pollinated by passerine birds in its native range (Búrquez 1989; Peters et al. 1995; Cronk and Ojeda 2008). A high rate of nectar secretion of very low solute concentration (4-10\% w/w), the absence of sucrose from the nectar, and the low amino acid concentration are all indicative of passerine bird pollination. In Europe, as reported by Búrquez (1989) and Peters et al. (1995), this ornamental plant is visited by blue tits (Parus caeruleus L.) and bumblebees, and ornithophily in crown imperial was confirmed by the fact that flowers visited by blue tits are efficiently pollinated and fertilized (Búrquez 1989). Even incidental ornithogamy in F. meleagris seems impossible, mainly due to inappropriate nectar composition and secondly because the flowers are not sufficiently robust to offer a suitable perch to feeding birds.

In our study plant, nectar was presented to pollinators for approx. 5-6 days (Zych and Stpiczyńska 2012). Similarly, nectar is available for 5 days in the Lilium hybrid Trésor, whereas in other Asiatic hybrids of Lilium, nectar was secreted only for 1 day (Lee and Chi 2002).

In $F$. meleagris, the mass of nectar secreted by the nectaries of the inner tepals was $20 \%$ higher than those of the outer tepals. However, nectary morphology are similar, irrespective of their position, and any variation in secretory activity might result from the somewhat larger tepals of the inner whorl. On the other hand, the Lilium hybrid Trésor displays a clear distinction between the perianth segments, but each petal and sepal produces a comparable amount of nectar sugars (Stolar and Davis 2010).

In $F$. meleagris nectar was composed of almost equal quantities of sucrose, glucose and fructose, and this balance did not change in successive stages of anthesis. Our results agree with the findings of Rix and Rast (1975) for the same species. However, in other species of Fritillaria investigated by these authors, nectar composition differed in particular taxonomic sections. For example, in $F$. imperialis no sucrose was detected, whereas members of the other series of section Trichostylae Boiss. showed that fructose was distinctly dominant to glucose. Conversely, in Lilium, sucrose was the most abundant nectar sugar (Stolar and Davis 2010). These results can probably be attributed to differences in pollinating agents, but field data for many Fritillaria and Lilium species are unfortunately scarce.

In the final stage of anthesis, the mass of nectar and its concentration declined significantly, which indicates that nectar resorption occurs in the flowers of $F$. meleagris. Nectar resorption is a long-known phenomenon, but has rarely been addressed in studies on nectar secretion (Pedersen et al. 1958; Southwick 1984; Pyke 1991; Búrquez and Corbet 1991; Nepi and Stpiczyńska 2008). Resorption of nectar has generally been demonstrated (as in Fritillary) during final stages of anthesis as a postpollination phenomenon (Koopowitz and Marchant 1998; Luyt and Johnson 2002) or following the completion of sexual stages in dichogamous flowers (Langenberger and Davis 2002). Its significance was generally recognized as a resource-recovery strategy, and resulted in at least partial recycling of metabolites invested in nectar production (Southwick 1984; Pyke 1991; Búrquez and Corbet 1991; Nepi and Stpiczyńska 2007). However, nectar resorption can also occur concomitantly with nectar secretion, as shown for Cucurbita pepo. Moreover, the modulation of these two contrasting processes (secretion and resorption) allows the maintenance of nectar composition within a range appropriate for pollinators (Nepi et al. 2007). It should be noted that in the European Fritillary, all nectar sugar constituents were resorbed to a similar degree, because the proportion of individual sugars at the final stage of anthesis remained almost unchanged. This result compares well with that obtained for Eucalyptus (Davis 1997).

Reclamation of nectar components in Fritillary is facilitated by the presence of micro-channels or pores in the cuticle that covers the secretory epidermis, as in Echinacea purpurea L. (Moench) (Wist and Davis 2006), P. chlorantha (Stpiczyńska 2003a) and C. pepo (Nepi et al. 2001). Also, in F. meleagris, the efficiency of nectar resorption is improved by the wall ingrowths present in the cells of the nectariferous epidermis and parenchyma, and these were still present at the final stages of anthesis, when nectar resorption occurs. Resorbed nectar can be translocated along the symplast and/or apoplast, and then transported in vascular tissue to the nearest major sink of assimilates. The route taken by secreted nectar was confirmed by autoradiographic studies of $P$. chlorantha. Here, resorbed sugars were translocated acropetally or basipetally along the whole inflorescence (Nepi and Stpiczyńska 2007).

\section{Nectary structure}

The nectaries of $F$. meleagris are located in grooves on the adaxial surfaces of each of the tepals (Knuth 1899). In general, the morphology of the nectaries of $F$. meleagris is similar to that reported by Bakhshi Khaniki and Persson (1997) for several species of the subgenus Fritillaria, the nectary of each possessing a lanceolate to linear outline. By contrast, in the subgenus Petilium (L.) Baker, which includes $F$. imperialis and $F$. raddeana, nectaries are circular, whereas those of the subgenus Rhinopetalum (Fisch. ex Alexand.) Baker, have nectaries that are deeply depressed and situated in sac-like projections that can 
either be symmetrical on each tepal or unequal. In the latter case, the flowers tend to be zygomorphic. Moreover, in the subgenus Rhinopetalum, the nectary surface is bordered by lobes or hairy ridges, like the perigonal nectaries of Lilium (Stolar and Davis 2010), whereas in F. meleagris, the surfaces of the nectary and tepals are completely glabrous. Details of the morphology and as well structure of nectaries could be important characters in determining classification and evolution of the genus Fritillaria and other Monocotyledons (Smets et al. 2000). However, up to date morphological aspects of the nectary in Asiatic Fritillaria were considered by Bakhshi Khaniki and Persson (1997) and structural aspects are still neglected.

In F. meleagris, the nectaries positioned on the tepals of the outer and inner whorls differed neither in their morphology nor their anatomy. Similarly, no evident morphological differences were reported for other species of the genus (Bakhshi Khaniki and Persson 1997).

The nectary of $F$. meleagris was composed of a secretory epidermis and several layers of nectariferous parenchyma. This model of nectary structure has been reported for many other plant species (Durkee 1983; Fahn 1979, 1988, 2000; Bernardello 2007; Nepi 2007; Davies and Stpiczyńska 2008), regardless of taxonomic position and nectary location (e.g. 'nectaria caduca' and 'nectaria persistentia' sensu Smets and Crescens 1988). Moreover, the secretory cells of $F$. meleagris share many features with the nectaries of other plant species in that they are small with large nuclei, small vacuoles and dense, intensely staining cytoplasm with abundant endoplasmic reticulum, dictyosomes and secretory vesicles. However, contrary to the majority of nectaries investigated, where amyloplasts or chloroamyloplasts were present at least in the pre-secretory stage, starch was not detected in the nectary cells of $F$. meleagris. Starchless plastids similar to those present in Fritillary, with numerous plastoglobuli and few internal membranes, have rarely been observed in nectary cells, e.g. in Gymnadenia conopsea (Stpiczyńska and Matusiewicz 2001) and Maxillaria coccinea (Jacq.) L.O. Williams ex Hodge (Stpiczyńska et al. 2004), but in the latter, the nectary was studied only at full anthesis. In the majority of nectaries studied, plastids usually became differentiated into amyloplasts, and these play an important role in nectar production. According to the mechanism postulated by Ren et al. (2007) for Nicotiana, starch stored in amyloplasts at the pre-secretory stage is hydrolysed during the secretory stage and serves both as a source of carbohydrate for nectar and as a source of energy to pump sugars from the phloem into the nectary. As starch was absent from the nectary cells of $F$. meleagris, sugars secreted in the nectar were probably delivered by the phloem sap, because nectariferous tissue was supplied with vascular bundles that ended in the subepidermal parenchyma. Van Die et al. (1970) showed that following application of ${ }^{14} \mathrm{C}$ to the leaves of $F$. imperialis, radioactive label appeared in the floral nectar, indicating that nectar assimilates can be translocated directly from leaves. Because plastids present in the nectariferous parenchyma cells of $F$. meleagris did not display characteristic red fluorescence (it is possible that such pale red dispersed autofluorescence is affected by the presence of anthocyanins), they are probably not engaged in contributing assimilates to the nectar, as recorded for other plant species (Pacini and Nepi 2007; Vassiliev 2010; Heil 2011).

The nectary cells of epidermal and subepidermal parenchyma of $F$. meleagris had unevenly thickened cell walls, the tangential walls being significantly thicker than the radial ones. Similarly thickened cell walls were recorded for the perigonal nectaries of Lilium (Stolar and Davis 2010). Moreover, collenchymatous cell walls have been reported for the nectaries of several orchid species, particularly those taxa pollinated by birds (Stpiczyńska et al. 2004; Davies et al. 2005). In Fritillary, as in other species, thick cell walls may serve as a route for nectar transport within nectary tissue, especially where cutinized barriers that could inhibit nectar flow are absent from the wall. Plasmodesmata connect secretory cells and are particularly common in radial cell walls where they may facilitate additional transport of nectar along the symplast. These models of pre-nectar movement along the apoplast and/or symplast within secretory tissue, as well as the process of secretion, were proposed by several researchers (Gunning and Hughes 1976; Kronestedt-Robards and Robards 1991; Nepi 2007; Vassiliev 2010; Heil 2011). Some studies used radiolabelled sugars to follow the route taken by sugars within the nectary (Shuel 1961; Fahn and Rachmilevitz 1975; Meyberg and Kristen 1981; Sawidis et al. 1989; Stpiczyńska 2003a, b; Nepi and Stpiczyńska 2007; Ren et al. 2007). According to Bush (1999), Williams et al. (2000) and Lemoine (2000), both pathways of sucrose transport may operate in the same plant, with particular routes favouring a specific organ, tissue or developmental stage. Sucrose may be imported into sink cells from the apoplast, either directly by sucrose transporters or by monosaccharide transporters following hydrolysis to glucose and fructose by cell wall invertase. Within the protoplasts of nectary cells, nectar undergoes a final modification and is subsequently secreted into the periplasmic space. Because in the nectary cells of $F$. meleagris both secretory vesicles and numerous mitochondria were present at the secretory stage, it is probable that sugars are actively transported across the plasmalemma and that a granulocrine mode of secretion operates here, as in the nectaries of many other plant species (Kronestedt-Robards and Robards 1991; Fahn 2000; Nepi 2007).

For the first time, we report the presence of transfer cells with prominent labyrinthine wall ingrowths for the 
perigonal nectaries of Fritillary. Cell wall ingrowths were absent from the perigonal nectaries of Lilium (Stolar and Davis 2010), but small cell wall ingrowths were observed for the septal nectaries of Tillandsia (Fiordi and Panandri 1982). Prominent wall ingrowths have also been recorded for the septal nectaries of Gasteria, Aloe (Schnepf and Pross 1976) and Strelitzia (Kronestedt-Robards and Robards 1987). However, cell wall ingrowths are a universal feature of plants and fungi, and can develop in the cells of many organs (for review see Offler et al. 2002). In $F$. meleagris, nectariferous cell wall ingrowths were particularly prominent on the tangential walls of epidermal and nectariferous parenchyma cells at the stage of maximum secretory activity. Generally, cells with wall ingrowths are frequently termed transfer cells, because the presence of wall ingrowths increases the surface area of the plasmalemma and thus improves transport capacity. The presence of wall ingrowths also frequently polarizes the direction of solute flow, and it is thought to facilitate the exchange of solutions between apoplast and symplast. Moreover, as in the case of $F$. meleagris, an endomembrane secretory system is located close to the wall ingrowths (Gunning and Pate 1969; Offler et al. 2002). It is possible that cell wall protuberances in $F$. meleagris facilitate the transport of nectar within the nectary, together with nectar secretion and nectar resorption during the final stage of anthesis, because they are still present and unchanged in nectariferous epidermal cells and subepidermal parenchyma. By contrast, the post-secretory stage cell wall underwent redifferentiation in the septal nectaries of Gasteria and Aloe; ingrowths disappeared and the cell wall became covered by a 'third layer' (Schnepf and Pross 1976). Thickening of the tangential cell wall was also reported for Tillandsia (Fiordi and Panandri 1982) and was mainly due to the accumulation of acid polysaccharides.

In the nectariferous cells of $F$. meleagris, callose was detected in cell walls at the secretory stage, as recorded for Aloe greatheadii var. davyana (Nepi et al. 2006). According to Offler et al. (2002, and references therein), callose is a common component of wall ingrowths and its presence is restricted to the outer layer between the ingrowth and the plasma membrane. The occurrence of callose may facilitate deposition of wall material and push the projections into the cytoplasm.

Usually, once secreted by the protoplast, nectar passes across the cell wall and can flow onto the surface of the nectary via modified stomata, a permeable cuticle or via pores/cracks in the cuticle (Nepi 2007). Modified stomata were absent from the epidermis of $F$. meleagris, and this is true of the floral nectaries of most monocots (Endress 1995). To date, the only known exception is the orchid Maxillaria anceps Ames and C. Schweinf. (Davies et al.
2005), where nectar is secreted via the stomata of the labellar callus. The thick layer of reticulate cuticle covering the surface of the secretory epidermis of $F$. meleagris did not pose a barrier to nectar secretion. Having crossed the outer cell wall, nectar accumulated beneath the cuticle, which became distended to form small swellings. At the beginning of nectar secretion (stage 1) these swellings were most frequently found at points coinciding with the middle lamella, between adjoining epidermal cells, and this may strengthen the hypothesis that in the nectary of $F$. meleagris, nectar passes along the apoplast before traversing the stretched cuticle, which at points becomes ruptured to form pores. These pores were particularly evident during the stage of maximum secretion. Similar cuticular pores have been recorded for the nectary hairs of Abutilon (Findlay and Mercer 1971). In some plants, however, the secretion is released via a disrupted cuticle, as in the nectaries of Limodorum abortivum (Pais and Figueiredo 1994). In others, such as Platanthera chlorantha (Stpiczyńska 2003a, b), the cuticle is completely permeable to secreted substances, as well as resorbed nectar. It is possible that changes to the chemical structure of the cuticle, as demonstrated by differences in autofluorescence during the secretory and postsecretory stages, may further facilitate the secretion and resorption of nectar.

Our studies indicate that $F$. meleagris is a homogamous plant, and that maximum nectar secretion by perigonal nectaries overlaps with the period of greatest pollen presentation. This greatly improves the effectiveness of pollination. Nectar unused by pollinators is resorbed during the final stage of anthesis. Despite real paths of nectar formation and resorption not being shown here, we speculate that cell wall ingrowths present in nectariferous cells may facilitate both nectar secretion and resorption.

Acknowledgments We thank Magdalena Kamińska, M.Sc., for help in the lab and for preparing illustrations, Katarzyna Roguz, B.Sc., for editing the manuscript, Karol Stpiczyński for helping with the field work, Dr. Narcyz Piórecki (Bolestraszyce Arboretum) for hospitality and information on F. meleagris populations in Przemyśl district and Ukraine, and Professor Jakub Dolatowski for translation of Knuth's (1899) description of F. meleagris. All experimental and observation work on protected plants was done in compliance with Polish law upon obtaining the permissions DOPog-421-II-1/05/jr and DLOPiK-op/ogiz-4211/I-91/6265/07/08/msz from the Ministry of Environment, Republic of Poland, DOPozgiz-4200/I-67.2/1071/ 10JRO from the General Directorate of Environment Protection, and R.V-6630/41/07 and RDO -18-WPN-6631-2-24/10/rn from the Regional Conservator of Nature in Rzeszów. The study was supported financially by the Ministry of Science and Higher Education, Republic of Poland, via grant N N304 131736 (to MZ and MS).

Open Access This article is distributed under the terms of the Creative Commons Attribution License which permits any use, distribution, and reproduction in any medium, provided the original author(s) and the source are credited. 


\section{References}

Baker H, Baker I (1983) A brief historical review of the chemistry of floral nectar. In: Bentley B, Elias $T$ (eds) The biology of nectaries. Columbia University Press, New York

Bakhshi Khaniki G (2007) Taxonomic revision of the genus Rhinopetalum (Liliaceae) in Iran. Plant Archiv 7:47-52

Bakhshi Khaniki G, Persson K (1997) Nectary morphology in South West Asian Fritillaria (Liliaceae). Nordic J Bot 17:579-611

Baum SF, Eshed Y, Bowman JL (2001) The Arabidopsis nectary is an ABC-independent floral structure. Development 128:4657-4667

Bernardello G (2007) Systematic survey on floral nectaries. In: Nicolson S, Nepi M, Pacini E (eds) Nectaries and nectar. Springer, Dordrecht

Búrquez A (1989) Blue tits, Parus caeruleus as pollinator of the crown imperial, Fritillaria imperialis, in Britain. Oikos 55:335-340

Búrquez A, Corbet SA (1991) Do flowers reabsorb nectar? Funct Ecol 5:369-379

Bush DR (1999) Sugar transporters in plant biology. Curr Opinion Plant Biol 2:187-191

Cronk Q, Ojeda I (2008) Bird-pollinated flowers in an evolutionary and molecular context. J Exp Bot 59:715-727

Davies KL, Stpiczyńska M (2008) Labellar micromorphology of two Euglossine-pollinated orchid genera; Scuticaria Lindl. and Dichaea Lindl. Ann Bot 102:805-824

Davies KL, Stpiczyńska M, Gregg A (2005) Nectar-secreting floral stomata in Maxillaria anceps Ames and C. Schweinf. (Orchidaceae). Ann Bot 96:217-227

Davis AR (1997) Influence of floral visitation on nectar-sugar composition and nectary surface changes in Eucalyptus. Apidologie 28:27-42

Durkee LT (1983) The ultrastructure of floral and extrafloral nectaries. In: Bentley B, Elias IT (eds) The biology of nectaries. Columbia University Press, New York

Endress PK (1995) Major evolutionary traits of monocot flowers. In: Rudall PJ, Cribb PJ, Cutler DF, Humphries CJ (eds) Monocotyledons: systematics and evolution. Royal Botanic Gardens, Kew

Fahn A (1979) Ultrastructure of nectaries in relation to nectar secretion. Am J Bot 55:977-985

Fahn A (1988) Secretory tissues in vascular plants. New Phytol 108:229-257

Fahn A (2000) Structure and function of secretory cells. Adv Bot Res 31:37-75

Fahn A, Rachmilevitz T (1975) An autoradiographical study of nectar secretion in Lonicera japonica Thunb. Ann Bot 39:975-976

Fay FM, Chase MW (2000) Modern concepts of Liliaceae with focus in the relationships of Fritillaria. Curtis's Bot Mag 17:146-149

Findlay N, Mercer FV (1971) Nectar production in Abutilon. I. Movement of nectar through the cuticle. Austral J Biol Sci 24:647-656

Fiordi AC, Panandri MR (1982) Anatomic and ultrastructural study of septal nectary in some Tillandsia (Bromeliaceae) species. Caryologia 35:477-489

Gahan PB (1984) Plant histochemistry and cytochemistry: an introduction. Academic, London

Goldblatt P, Manning J (2008) The iris family: natural history and classification. Timber, Portland

Gunning BES, Hughes IE (1976) Quantative assessment of symplastic transport of pre nectar into trichomes of Abutilon nectaries. Austral J Plant Physiol 3:619-637

Gunning BES, Pate JS (1969) "Transfer cells" plant cells with wall ingrowths, specialized in relation to short distance transport of solutes-their occurrence, structure, and development. Protoplasma 68:107-133
Hedström I (1983) Kungsängsliljans pollinationsekologi. Svensk Bot Tidskr 77:313-325

Heil M (2011) Nectar: generation, regulation and ecological functions. Trends Plant Sci 16:191-200

Heslop-Harrison Y (1977) The pollen stigma interaction: pollen tube penetration in Crocus. Ann Bot 41:913-922

Jensen WA (1962) Botanical histochemistry: principle and practice. Freeman, San Francisco

Johansen DA (1940) Plant microtechnique. McGraw-Hill, New York

Knuth P (1899) Handbuch der Blütenbiologie. Lobeliaceae bis Gnetaceae. Verlag von Wilhelm Engelman, Leipzig, Band II

Koopowitz H, Marchant TA (1998) Postpollination nectar reabsorption in the African epiphyte Aerangis verdickii (Orchidaceae). Am J Bot 85:508-512

Kronestedt-Robards E, Robards AW (1987) Sugar secretion from the nectary of Strelitzia: an ultrastructural and physiological study. Protoplasma 137:168-182

Kronestedt-Robards E, Robards AW (1991) Exocytosis in gland cells. In: Hawes CR, Coleman JOD, Coleman DE (eds) Endocytosis, exocytosis and vesicle traffic in plants. Cambridge University Press, Cambridge

Langenberger MW, Davis AR (2002) Temporal changes in floral nectar production, reabsorption, and composition associated with dichogamy in annual caraway (Carum carvi; Apiaceae). Am J Bot 89:1588-1598

Lee X-K, Chi H-S (2002) The analysis of nectar and the observation of nectary structure of Lilium spp. J Agri Ass China 3:37-47

Lemoine R (2000) Sucrose transporters in plants: update on function and structure. Biochim Biophys Acta 1465:246-262

Luyt R, Johnson SD (2002) Postpollination nectar resorption and its implications for fruit quality in an epiphytic orchid. Biotropica 34:442-446

Meyberg M, Kristen U (1981) The nectaries of Aptenia cordifolia ultrastructure, translocation of ${ }^{14} \mathrm{C}$-labelled sugars, and possible pathway of secretion. Zeitsch Pflanzenphysiol 104:139-147

Nepi M (2007) Nectary structure and ultrastructure. In: Nicolson S, Nepi M, Pacini E (eds) Nectaries and nectar. Springer, Dordrecht

Nepi M, Stpiczyńska M (2007) Nectar resorption and translocation in Cucurbita pepo L. and Platanthera chlorantha (Custer) Rchb. Plant Biol 9:93-100

Nepi M, Stpiczyńska M (2008) The complexity of nectar: secretion and resorption dynamically regulate nectar features. Naturwissenshaften 95:177-184

Nepi M, Guarnieri M, Pacini E (2001) Nectar secretion, reabsorption, and sugar composition in male and female flowers of Cucurbita pepo. Int J Plant Sci 162:353-358

Nepi M, Human H, Nicolson SW, Cresti L, Pacini E (2006) Nectary structure and nectar presentation in Aloe castanea and A. greatheadii var. davyana (Asphodelaceae). Plant Syst Evol 257:45-55

Nepi M, Guarnieri M, Artese D, Cresti L, Stpiczyńska M, Pacini E (2007) Dynamics of nectar production and reabsorption in Cucurbita pepo. 9-th international pollination symposium on plant-pollinator relationships-diversity in action. Ames Iowa (USA) 24-28 June, pp 34-35

O'Brien TP, McCully ME (1981) The study of plant structureprinciples and selected methods. Termarcarphi Pty, Melbourne

Offler CE, McCurdy DW, Patrick JW, Talbot MJ (2002) Transfer cells: cells specialized for a special purpose. Ann Rev Plant Biol $54: 431-454$

Pacini E, Nepi M (2007) Nectar production and presentation. In: Nicolson S, Nepi M, Pacini E (eds) Nectaries and nectar. Springer, Dordrecht

Pacini E, Nepi M, Vesprini J (2003) Nectar biodiversity: a short review. Plant Syst Evol 238:7-21 
Pais MS, Figueiredo ACS (1994) Floral nectaries from Limodorum abortivum (L.) Sw. and Epipactis atropurpurea Rafin. (Orchidaceae): ultrastructural changes in plastids during the secretory process. Apidologie 25:615-626

Pedersen MW, LeFevre CW, Wiebe HH (1958) Absorption of $\mathrm{C}^{14}$ labelled sucrose by alfalfa nectaries. Science 127:758-759

Percival M (1961) Types of nectar in angiosperms. New Phytol 60:235-281

Peters WS, Pirl M, Gottsberger G, Peters DS (1995) Pollination of the Crown Imperial Fritillaria imperialis by Great Tits Parus major. J Ornitholog 136:207-212

Pyke GH (1991) What does it cost a plant to produce floral nectar? Nature 350:58-59

Ren G, Healy RA, Klyne AM, Horner HT, James MG, Thornburg RW (2007) Transient starch metabolism in ornamental tobacco floral nectaries regulates nectar composition and release. Plant Sci 173:277-290

Reynolds ES (1963) The use of lead citrate at high $\mathrm{pH}$ as an electronopaque stain in electron microscopy. J Cell Biol 17:208-212

Rix EM (1968) Fritillaria L. In: Tutin TG et al (eds) Flora Europea, vol 5. Cambridge University Press, Cambridge

Rix EM, Rast D (1975) Nectar sugars and subgeneric classification in Fritillaria. Biochem Syst Ecol 2:207-209

Rønsted N, Law S, Thornton H, Fay MF, Chase MW (2005) Molecular phylogenetic evidence for the monophyly of Fritillaria and Lilium (Liliaceae; Liliales) and the infrageneric classification of Fritillaria. Mol Phylogen Evol 35:509-527

Rudall PJ, Stobart KL, Hong W-P, Conran JG, Furness CA, Kite GC, Chase MW (2000) Consider the lilies: systematics of Liliales. In: Wilson KL, Morrison DA (eds) Monocots: systematic and evolution. CSIRO, Collingwood

Rudall PJ, Manning JC, Goldblatt P (2003) Evolution of floral nectaries in Iridaceae. Ann Miss Bot Gard 90:613-631

Sawidis T, Heinrich G, Tsekos I (1989) Autoradiographical study of the incorporation of tritium labelled glucose (D-glucose-6- $\left.\mathrm{H}^{3}\right)$ in floral nectaries of Abutilon striatus (Dicks). Bios 1:211-219

Schnepf E, Pross E (1976) Differentiation and redifferentiation of a transfer cell. Development of septal nectaries of Aloe and Gasteria. Protoplasma 89:105-115

Shuel RW (1961) Influence of reproductive organs on secretion of sugars in flowers of Streptosolen jamesonii Miers. Plant Physiol 36:265-271

Simpson BB, Neff JL (1983) Evolution and diversity of floral rewards. In: Jones CE, Little RL (eds) Handbook of experimental pollination biology. Van Nostrand and Reinhold, New York pp 142-159
Smets EF, Crescens EM (1988) Types of floral nectaries and the concepts 'character' and 'character-state' - a reconsideration. Acta Bot Neerland 37:121-128

Smets EF, Decraene L-PR, Caris P, Rudall PJ (2000) Floral nectaries in Monocotyledons: distribution and evolution. In: Wilson KL, Morrison DA (eds) Monocots: systematics and evolution. CSIRO, Melbourne

Southwick E (1984) Photosynthate allocation to floral nectar: a neglected energy investment. Ecology 65:1775-1779

Stolar J, Davis AR (2010) Floral nectary structure, nectar production, and carbohydrate composition in the Lilium Asiatic hybrid 'Trésor. Botany 88:185-205

Stpiczyńska M (2003a) Nectar resorption in the spur of Platanthera chlorantha (Custer) Rchb.- structural and microautoradiographic studies. Plant Syst Evol 238:119-126

Stpiczyńska M (2003b) Incorporation of $3 \mathrm{H}$-sucrose after the resorption of nectar from the spur of Platanthera chlorantha (Custer) Rchb. Can J Bot 81:927-932

Stpiczyńska M, Matusiewicz J (2001) Anatomy and ultrastructure of the spur nectary of Gymnadenia conopsea L. (Orchidaceae). Acta Soc Bot Pol 70:267-272

Stpiczyńska M, Davies KL, Gregg A (2004) Nectary structure and nectar secretion in Maxillaria coccinea (Jacq.) L.O. Williams ex Hodge (Orchidaceae). Ann Bot 93:87-95

van Die J, Leeuwangh P, Hoekstra SMR (1970) Translocation of assimilates in Fritillaria imperialis L. 1. The secretion of ${ }^{14} \mathrm{C}$-labelled sugars by the nectaries in relation to phylotaxis. Acta Bot Neerland 19:16-23

van Wyk BE (2002) The systematic value of nectar sugar composition in higher plants. In: Nectar and nectary: from biology to biotechnology. Proc. Intern. Conference, May 28-31 Siena, Italy

Vassiliev AE (2010) On the mechanism of nectar secretion: revisited. Ann Bot 105:349-354

Vogel S (1998) Floral biology. In: Kubitzki K (ed) The families and genera of vascular plants. Volume III. Flowering plants Monocotyledons Lilianae (except Orchidaceae). Springer, Heidelberg

Williams LE, Lemoine R, Sauer N (2000) Sugar transporters in higher plants - a diversity of roles and complex regulation. Trends Plant Sci 5:283-290

Wist TJ, Davis AR (2006) Floral nectar production and nectary anatomy and ultrastructure of Echinacea purpurea (Asteraceae). Ann Bot 97:177-193

Zych M, Stpiczyńska M (2012) Neither protogynous nor obligatory out-crossed: pollination biology and breeding system of the European red-list Fritillary Fritillaria meleagris L. (Liliaceae). Plant Biol 14:285-294. doi:10.1111/j.1438-8677.2011.00510.x 